\title{
Flight and Ground Safety: Comparing Teaching and Business Practices
}

\author{
William R. Caldwell, Edwin D. Phillips, and Katie Lake \\ Southern Illinois University Carbondale
}

\begin{abstract}
This study investigates how UAA affiliated aviation programs safety course content compares to the safety programs and concerns of the airline industry. Airlines have experienced very few flight safety accidents and incidents during the past five years. During the same period airline employees have experienced ground related injuries at a very high rate compared to other industries. The research concludes that UAA educational programs should be reviewed to ensure adequate attention is being given to ground safety topics.
\end{abstract}

\section{INTRODUCTION}

\section{Background}

Business concern for producing safe products and services in the United States has increased with the growth of litigation. The aerospace industry is no exception to this, and since the industry places its customers in the potentially hazardous environment of flight, it is particularly concerned and heavily invested in minimizing customer risk and projecting of an image of totally safe operations.

University aviation programs have long recognized this driving concern within the aerospace industry and generally provide one or more safety courses for their students. The nature of these courses in the sense of what areas of safety they discuss is a common discussion item among faculty that teach these courses, raising the question of what should be taught to best support the needs of the industry that will hire their students.

Multiple safety topics might be included within a safety course or curriculum. For example, industrial safety, traffic safety, flight line safety, airport environment safety, hazardous materials safety, maintenance safety, flight operations safety, crew resource management, aviation physiology, systems safety, OSHA, and safety program management topic could be discussed.

The authors' anecdotal review of UAA presentations, articles and committee actives leads to the perception that the significant majority of discussion and writing in academia is about is directed toward flight safety and little or none involves ground safety or any of the other topics listed above. Yet, the Air
Transportation Association (ATA), the professional group representing 18 major airlines (ATA, 2007a), has separate committees for flight and ground safety (ATA, 2007b). The ATA defines flight safety and ground safety by the hazards that affect safety in each area. The ATA flight safety committee and the ground safety committee divide their activities as shown below (ATA, personal communication, January 12, 2007):

\section{Flight Safety}

- Issues Involving the Operation of Aircraft when Intent for Flight Exists

- Flight Accident/Incident Investigations,

- Runway Incursions,

- Rejected Takeoffs,

- Turbulence Injuries

- Wildlife Strikes.

Ground Safety

- Issues Involving Ground Damage to Aircraft

- Injury to Personnel Involved In Ground Servicing, Maintenance, Towing/Taxi for Purposes Other than Revenue Flight

- Human Factors,

- Operation/Safe Driving,

- Ergonomics,

- Materials Safety Data Sheets,

- Dg/HAZMAT,

- Marshalling,

- Taxi Signals,

- Ramp Operations During Inclement Weather, 
- Ground Accident/Incident Investigation, and Inadvertent Emergency Exit Operations,

- Passenger Loading Bridge Events,

- Hazard Awareness,

- Personal Safety,

- OSHA Requirements,

- Environmentally-Sensitive Ops in the AOA.

Some readers may argue that safety is safety and flight and ground safety should not be considered separately. Others may argue there are some differences but much overlap. Another group of individuals may say safety is divided into various categories such as maintenance safety, industrial safety, etc., and each area must be addressed. Our position is to accept the practice of the ATA which has two functional areas for aviation safety.

The purpose of this study is to determine how UAA affiliated aviation programs safety course content compared to the safety programs and concerns of the airline industry. To do this the authors addressed these seven research questions:

1. Using the subtopic areas of the ATA definitions of flight and ground safety, what is the amount of emphasis placed on ground and flight safety in UAA affiliate safety courses?

2. In which areas of safety do airline managers place emphasis?

3. What is the balance between ground and flight safety topics in aviation publications and research?

4. What is the balance between ground and flight safety activity in ATA member airlines?

5. What percentage of UAA affiliated aviation schools has a safety course?

6. What textbooks are used for these courses?

7. What is the balance between ground and flight safety accidents/incidents incurred by ATA member airlines?

\section{Definitions}

Safety - The lack of hazards that can produce injury or death of a person or significant damage or destruction of other resources.
Safety Program - Actions taken by some entity to create safety.

\section{Limitations}

This discussion is limited to the University Aviation Association (UAA) member schools that offer a four-year bachelor degree in aviation management as identified by Phillips (2004) and to the United States based member airlines of the Air Transport Association. Both the UAA and ATA represent the major players in their respective industry of aviation education and aviation operations. Civilian and military aviation and practices of non-US based schools and airlines are excluded.

\section{LITERATURE REVIEW}

The literature review was conducted in three phases. Phase one reviewed the top three journals in aviation education. Phase two reviewed the text books commonly used in aviation education. Phase three reviewed public records to determine the extent of accidents and injuries in the flight and ground environment.

\section{Journal Review}

Johnson, Gibson, Hamilton and Hanna (2006) identify the three most important peerreviewed journals in aviation education. They are the Collegiate Aviation Review, Journal of Aviation/Aerospace Education \& Research, and the Journal of Air Transportation. The review of these journals indicates to what degree flight and ground safety are the subject of published articles and if any prior investigation was made of the issue addressed in this study. The most recent five-year time period, 2002 through 2006, was selected as an arbitrary standard. During this period we located 19 articles dealing with safety. Fourteen articles concern flight safety, three ground safety, and one system safety. A brief summary of these articles is provided below.

\section{Flight Safety Articles}

Kirton (2004) indirectly describes in-flight safety as a means of avoiding "traffic conflict." "Traffic conflict" is defined as "...any situation involving another aircraft in the pattern that required either pilot to maneuver to avoid a midair collision" (p.17). This definition implies "in-flight" safety as an activity that is completed 
in order to escape an in-flight mishap. Patrick Ross (2004) discussed the need for checklists during all aspects of flight. Checklist usage can reduce the chances for accidents/incidents. Ross describes "in-flight" safety as performing necessary checklists and avoiding conflict resulting from improper usage. According to Adams (2005), "flight safety" is generalized to mean ground and in-flight safety. No references to ground accidents are mentioned in the article. Adams specifically mentions the 1956 midair collision over the Grand Canyon involving a DC-7 and Super Constellation. Olson and Austin (2005) make no distinction between ground and in-flight safety; however, safety in general is categorized as the reduction of flight accidents/incidents.

Young, Fanjoy and Suckow (2006) see "safety" as perfecting in-flight activities including situational awareness, manual flying skills and automated cockpits. In CampbellLaird's (2006) article on phraseology and communication in collegiate flight training programs, flight safety is measured by the rate of accidents and incidents, and no other mention of safety was made. Flouris, and Reyes, (2006) indicated that airline safety performance is determined by rate of accidents and incidents. There was no distinction between ground accidents/incidents and in-flight accidents/incidents, rather the article concentrates on in-flight safety. Witiw, Lanier and Crooks (2003), targeted pilot decisionmaking in adverse weather conditions, specifically, decisions regarding additional weather information obtained en route. Although not specifically mentioned, the article concentrated on in-flight safety (pilot decisionmaking and situational awareness) according to the ATA.

Cocklin (2004) discussed checklists and inflight safety with emphasis on in-flight emergencies. Gill (2004) offers a definition of safety by Lowrance (1976), “....a judgment of the acceptability of risk, and risk, in turn, as a measure of the probability and severity of harm to human health" (p. 44). Gill (2004) concludes that according to Helmreich and Meritt (2001) "The findings of this study support the notion that safety is somewhat subjective and therefore difficult to conceptualize, as it varies in different environments." Gill (2004) states that violations of safety are considered in-flight safety as defined by the Air Transport Association. Finger and Piers (2005) define safety performance (in-flight safety) as the rate of accidents and incidents. Finally, Lee, Fanjoy and Dillman (2005), focus on flight safety not ground safety and discuss pilots' aeronautical decision-making (ADM), situational awareness, and training experience.

\section{Ground Safety Articles.}

McNamara, Thom and Thompson (2004) state that being safe on the ramp encompasses ground safety. They conclude that the lack of ground safety related to accidents like ValuJet Flight 592, Alaska Airlines Flight 261, TWA Flight 800 and Air Midwest Flight 5481 "....alerted the air transportation industry that non-flight operation does play a significant role in today's aviation safety. As a result, the task of eliminating non-flight errors cannot be overemphasized" (p. 33). Rhoades, Reynolds, Waguespack Jr. and Williams (2005) state ground safety, specifically airline ground safety, is discussed as line maintenance and its quality of service. This is the basis of maintenance resource management (MRM) programs.

\section{System Safety Articles}

System safety involves general programs or practices which may be applied to ground or flight safety problems. According to Lee and Weitzel (2005), in-flight safety is described as accidents/incidents having resulted in fatalities and the subsequent investigation. Hansen and Pitts (2005) discuss system safety as related to the Mercury space program and NASA history. Their article indicates system safety is comparable to in-flight safety as they both focus on preventive accident measures.

In summary, the preponderance of research published in the top peer-reviewed journals in aviation education addresses flight safety or ground safety issues impacting flight worthiness. To validate this finding, the authors did a quick search of the FAA database (FAA, n.d.). This review revealed 8420 documents on ground safety as compared to 33,400 documents on flight safety. Clearly, the safety emphasis in the aviation industry has been on flight safety with 
only $20-25 \%$ of journal articles and other literature addressing ground safety topics.

\section{Text Book Review}

The three most common text books used in safety education in aviation management programs in UAA member schools are (1) The Fundamentals of Occupational Safety and Health by Friend and Kohn (2006),

Commercial Aviation Safety by Wells and Rodrigues (2004), and (3) Aviation Safety Programs: A Management Handbook by Woods (2003). Some programs use self-developed materials and other resources to support their curricula. The following paragraphs briefly discuss the primary resources.

The basic concepts of safety are extremely well presented by Friend and Kohn (2003). While this book is intended to introduce the student to Occupational Safety and Health concepts, it does a tremendous job of introducing general ideas and practices applied to all safety areas. It takes the reader from safety legislation and applicable laws such as worker compensation and the Occupational Safety and Health Act, through all of the programs and concepts dealing with ground safety, accident causation and investigation, hazardous material safety, and industrial safety. It also includes chapters on workplace violence and terrorism. It is well written, easy to read and could be a foundation resource in any safety education program, including aviation safety programs. While this textbook is very inclusive, it does not specifically discuss aviation safety concerns such as maintenance, flight line, or flight safety.

Wells and Rodrigues (2004) have produced a textbook that applies many of the concepts discussed by Friend and Kohn (2003) to aviation safety. It expands federal safety program information to include the FAA and NTSB and covers rulemaking by the FAA, EPA, and OSHA. It adds to the University of Southern California's "Four-M" accident causation model discussed by Friend and Kohn by discussing the effect of mission to potential cause elements and also introduces the management causation model developed by James Reason. It then turns to factors that directly affect aviation safety programs such as human factors, air traffic control, aircraft safety systems, airport safety, and airline safety. This text lives up to its title by limiting its comments to commercial-primarily airline--aviation safety programs. Little information is provided on maintenance safety issues but some information is provided on flight line safety. While many of the concepts and practices discussed are applicable to general aviation the book does not address small aircraft, corporate, or contract aviation.

Richard Wood (2003) has produced a practical handbook for aviation managers and safety personnel to use. It is in reality not a textbook but, as titled, a handbook to be used in the day-to-day efforts of aviation managers. Wood, a working expert in aviation safety ( $\mathrm{p}$. iii), presents a very practical approach to introducing aviation students to the concept of aviation safety and practices commonly used in this field. It is written by and takes pains to cover the key ideas discussed by Wells and Rodrigues, and Friend and Kohn. The book introduces the impact of safety on economics, basic concepts, terms, programmatic elements, and risk management. It discusses the human element of aviation safety and the elements of a solid safety program including reporting and distribution systems, inspection and safety education programs, and other information leading up to a sample aviation safety program. The book provides a series of checklists that safety personnel can use to achieve their program. Wood goes through a lot of information in easy to read short chapters always from the perspective of one who lived what he recommends.

\section{Public Records}

Federal law requires those who operate airplanes to provide the NTSB notification of “...aviation accidents and certain incidents. An accident is defined as an occurrence associated with the operation of an aircraft that takes place between the time any person boards the aircraft with the intention of flight and all such persons have disembarked, and in which any person suffers death or serious injury, or in which the aircraft receives substantial damage" (NTSB, 2007, Para. 1). Figure 1 shows the number of fatalities and serious injuries occurred by U.S. commercial airlines (FAA Part 121 carriers) for 
each of the most recent five years. Flight crew injuries are not included. The ATA position on this record was stated at a 2005 U. S. Senate Hearing on Aviation Safety, "Without question, scheduled air service is incredibly safe, and our goal is to build on that safety record" (Barimo,

\begin{tabular}{|c|c|c|c|c|}
\hline Year & $\begin{array}{c}\text { Passenger } \\
\text { Fatalities }\end{array}$ & $\begin{array}{c}\text { Passenger } \\
\text { Serious } \\
\text { Injuries }\end{array}$ & $\begin{array}{c}\text { Total Passenger } \\
\text { Enplanements } \\
\text { (millions) }\end{array}$ & $\begin{array}{c}\text { Million Passenger } \\
\text { Enplanements per } \\
\text { Passenger Fatality }\end{array}$ \\
\hline 2002 & 0 & 11 & 619 & No Fatalities \\
\hline 2003 & 19 & 10 & 654 & 34.4 \\
\hline 2004 & 11 & 3 & 711 & 64.6 \\
\hline 2005 & 18 & 2 & 743 & 41.3 \\
\hline 2006 & 47 & 4 & 750 & 16.0 \\
\hline
\end{tabular}

Figure 1. NTSB report of Passenger Injuries and Injury Rates

The Occupational Safety and Health Administration, under the Department of Labor, is responsible for assuring "the safety and health of America's workers by setting and enforcing standards; providing training, outreach, and education; establishing partnerships; and encouraging continual improvement in workplace safety and health" (OSHA, 2007, p. 1). The Administration is concerned with workplace safety for 115 million workers at 7 million worksites. Worker injuries are viewed from the perspective of number of incidents of injuries and the number of cases in which an injury caused the employee to miss at least some time away from work. The latter is called by some individuals in industry a losttime-injury or "LTI." OSHA reports LTI's as a rate of injuries per 100 full-time workers. By using this rate of injuries, comparison may be made between industries and companies with differing employee populations. The calculation considers a full-time worker an individual expected to work 40 hours per week, for 50 weeks or a total of 2000 hours per year (Bureau of Labor Statistics, 2006).

Commercial airlines fall within the North American Industry Classification System (NAICS) category 4811 - "Scheduled Air Transportation." According to the U.S. Census Bureau (2007), the description of this category is:

This industry group comprises establishments primarily engaged in
2005). Neither the FAA or the NTSB provide a summary of injuries beyond fatalities and serious injuries that occur to passengers and or crew members engaged in commercial aviation.

providing air transportation of passengers and/or cargo over regular routes and on regular schedules. Establishments in this industry operate flights even if partially loaded. Establishments primarily engaged in providing scheduled air transportation of mail on a contract basis are included in this industry (p. 1).

Figure 2 indicates that for the last three years Scheduled Air Transportation has essentially the worst lost-time-injury record in the nation among all industries. (Data has not been published for 2006.) Based on this report a representative record for an airline with 50,000 employees might have experienced 2,800 losttime injuries during $2005(5000 \times 5.6$ injuries per 100 employees $=2,800$ injuries).

Imagine Southwest's Midway Airport station manager's perplexity last December when "Wrestling suitcases on and off planes got so grueling for Southwest Airlines' 350 ramp workers in Chicago that by Christmas season one-fourth of them were reporting on-the-job injuries" (Trottman \& Carey, 2007). The station operation must have been impacted by this $25 \%$ injury rate!

In 2005 and 2006, OSHA sent letters to the 14,000 workplaces with the highest occupational injury and illness rates " ... urging the employers to take action to remove hazards causing the high rates." These locations "had 6.0 or more injuries or illnesses which resulted in days away from work, restricted work, or job transfer. The 
national average is 2.5." (OSHA, 2005; 2006). (Injuries reported are for 100 equivalent workers.) Of these 14,000 companies, 131 airline workplaces are included in 2005 and 129 in 2006. A workplace may be a single station or large department within the airline. (The airline workplaces may be understated because overnight carriers DHL, FedEx and UPS are not included in these summary numbers.)

$\begin{array}{ccl}\text { Year } & \begin{array}{c}\text { Ratio of Lost- } \\ \text { time Injuries } \\ \text { per 100 Workers }\end{array} & \text { National Ranking } \\ 2005 & 5.6 & \text { Second (worst) } \\ 2004 & 5.5 & \text { First (worst) } \\ 2003 & 6.2 & \text { First (worst) }\end{array}$

Figure 2. Bureau of Labor Statistics reports of lost-time-injuries for Scheduled Air Transportation (NAICS 4811)

The public record indicates that the airlines have an exemplary record of operating aircraft but a less than desirable record of employee injuries associated with the activities required to run the airline. The ATA and perhaps the public find the flight safety record is acceptable; the ground safety record appears not to be.

\section{METHODOLOGY}

In addition to the literature review, new data gathering for this study involved two steps:

1. Survey the instructors of safety courses taught at UAA aviation management schools. The intent of the survey is to learn what percent of each safety class is directed toward flight and to ground safety. A survey instrument is included in Appendix A. Forty-eight surveys were mailed and 31 $(65 \%)$ were returned.

2. Survey the head safety officer for airline members of the ATA. The survey instrument is included in Appendix B. The intent is to determine the emphasis on flight versus ground safety in safety committee meetings and the annual management appraisal process of key categories of airline managers. Nineteen surveys were mailed and eight $(42 \%)$ were returned. In both cases a cover letter described the purpose of the survey and the explanatory information about surveys required by our organization's research department.

\section{SURVEY RESULTS}

\section{Teaching Practices}

Appendix $\mathrm{C}$ portrays the information reported on the surveys. Effort in the classroom is $53 \%$ directed toward flight safety, $30 \%$ ground safety and 17\% toward other categories such as security, NTSB procedures, and a management viewpoint of safety. Part of the emphasis on flight safety may be that three of the safety courses are titled "flight safety."

\section{Airline Practices}

Six of the eight responding airlines indicated the existence of a system-level cross functional safety committee. The percent of dialog on flight and ground safety varied and is shown in Figure 3.

\begin{tabular}{|c|c|}
\hline \multicolumn{2}{|c|}{ Airline System Safety Committee Dialog } \\
\hline \% Flight Topics & $\%$ Ground \\
\hline \multicolumn{2}{|l|}{ Topics } \\
\hline 75 & 25 \\
\hline 70 & 30 \\
\hline 60 & 40 \\
\hline 50 & 50 \\
\hline 40 & 60 \\
\hline 30 & 70 \\
\hline
\end{tabular}

Figure 3. Airline Safety Concerns

The variance is apparently based on company practice and not associated with the size of the carrier. The two largest legacy carriers which responded are at each end of the spectrum.

Five carriers reported cross functional safety committees at their larger station. A cargo carrier reported 50\% discussion about flight safety and $50 \%$ on ground safety. The other four carriers report $20 \%$ to $0 \%$ about flight safety. The emphasis is clearly on ground safety.

All carriers report the existence of a safety component in the annual objectives of managers in operational positions. Figure 4 displays the spread of emphasis. 


\begin{tabular}{lcccccccc}
\hline $\begin{array}{c}\text { Type of } \\
\text { Airline }\end{array}$ & \multicolumn{2}{c}{$\begin{array}{c}\text { Flight } \\
\text { Operations Mgrs }\end{array}$} & \multicolumn{2}{c}{$\begin{array}{c}\text { Maintenance } \\
\text { Mgrs }\end{array}$} & \multicolumn{2}{c}{$\begin{array}{c}\text { Station } \\
\text { Operations }\end{array}$} & \multicolumn{2}{c}{$\begin{array}{c}\text { Onboard } \\
\text { Service }\end{array}$} \\
\hline & Flight & Ground & Flight & Ground & Flight & Ground & Flight & Ground \\
\hline Major & 95 & 5 & 80 & 20 & 5 & 95 & 75 & 25 \\
Major & 90 & 10 & 60 & 40 & 40 & 60 & 90 & 10 \\
Major & 90 & 10 & 70 & 30 & 20 & 80 & 80 & 20 \\
Major & Not reported & Not reported & Not reported & Not reported \\
Cargo & 70 & 30 & 30 & 70 & 10 & 90 & Not applicable \\
Cargo & 100 & 0 & 50 & 50 & 25 & 75 & Not applicable \\
Cargo & 100 & 0 & 50 & 50 & 10 & 90 & Not applicable \\
Regional & 50 & 50 & 50 & 50 & 20 & 80 & 50 & 50 \\
\hline
\end{tabular}

Figure 4. Extent Flight and/or Ground Safety Emphasized in Managers' Annual Objectives—shown as a percentage.

\section{CONCLUSION AND RECOMMENDATIONS}

The literature review and survey results point to the following conclusions:

1. The amount of emphasis placed on ground and flight safety in UAA affiliate safety courses leans steeply to flight safety issues and programs. Fifty-three percent of the reporting schools offered flight safety content in their safety courses, $30 \%$ offered ground safety content, and $17 \%$ offered related safety topics.

2. Operational airline managers tend to have a safety component in their annual evaluation. The predominant emphasis among ground and flight safety depends on the manager's functional area. As shown in Figure 4, flight operations, maintenance, and onboard service managers were graded primarily in flight safety areas while the station managers were graded primarily in ground safety areas.

3. The balance between flight safety topics in aviation publications and research was approximately 5 to 1 in favor of flight safety topics.

4. At a system level slightly more emphasis is placed on flight than ground safety, but airline system safety committees place at least $25 \%$ of their emphasis on ground safety. At a large station level the key emphasis is clearly on ground safety.
5. All of UAA affiliated aviation schools that responded to our survey have some sort of a safety course.

6. The most popular textbooks used for UAA affiliated courses are (1) The Fundamentals of Occupational Safety and Health by Friend and Kohn, (2) Commercial Aviation safety by Wells and Rodrigues, and (3) Aviation Safety Programs: A Management Handbook by Wood. The literature available to support college-level safety courses dealing with ground safety topics is limited.

7. ATA member airlines have exemplary flight safety records and yet have among the highest rate of lost-time occupational injuries reported by OSHA.

These conclusions lead to the following recommendations:

1. While a comparison of airline safety interests and aviation school safety course content seems to be balanced, aviation schools should consider adjusting course content to provide students an overview of ground safety topics as well as flight safety topics.

2. Textbooks written for safety courses need to deal more with flight line, maintenance, and hazardous materials safety.

3. Academic researchers in aviation should be encouraged to study and publish information pertaining to ground safety issues. 


\section{REFERENCES}

Adams, A. W. (2005). The effects of air traffic control privatization on operating cost and flight safety by collegiate aviation review. Journal of Aviation/Aerospace Education \& Research, 14(3), 21-27.

Air Transport Association (a). (2007). ATA Airline Members. Retrieved March 20, 2007 from http://www.airlines.org/products/membership/.

Air Transport Association (b). (2007). ATA Council/Committee Structure. Retrieved March 20, 2007 from $\quad$ http://www.airlines.org/NR/rdonlyres/DBB14E9E-F564-4EB6-89E3-56E94FF20381/0/ ATACouncilOverview.pdf.

Barimo, B. J. (2005, November 17). Hearing on Aviation Safety. U.S. Senate Committee Hearing on Commerce, Science and Transportation. Retrieved June 19, 2007 from http://www.airlines.org/NR/rdonlyres/94F0AFF8-29AB-4C1C-AAA2DD7CF613ECE1/0/AviationSafetyBasilCommerce1105.pdf.

Bureau of Labor Statistics (BLS). (2006). OS TB 10/19/2006 Table: SNR03. Highest rates for cases with days away from work - Inj/Ill - 2005. Retrieved 11/2/07 from http://www.bls.gov/ iif/oshwc/osh/os/ostb1477.pdf).

Campbell-Laird, K. (2006). Pedagogical approaches to aviation phraseology and communication training in collegiate flight programs. Collegiate Aviation Review, 24(1), 25-35.

Cocklin, J. T. (2004) Swissair 111 human factors: Checklists and cockpit communication. Journal of Air Transportation, 9(3), 19-42.

Federal Aviation Administration (FAA). (n.d.). FAA Search. Retrieved on 11/6/07, from http:// FAASearchProcess.asp? $\mathrm{q}=$ flight + safety $\& b \operatorname{tnG}=$ Search\&output $=\mathrm{xml}$ no dtd\&sort $=$ date $\% 3 \mathrm{AD} \% 3 \mathrm{~A}$ $\mathrm{L} \% 3 \mathrm{Ad} 1 \& \mathrm{ie}=\mathrm{UTF}-8 \& \mathrm{client}=$ default_frontend\&oe $=\mathrm{UTF}-8 \&$ proxystylesheet $=$ default_frontend\&site $=$ FAA Pages.

Finger, M. \& Piers, M. (2005). Air transport regulation under transformation: The case of Switzerland. Journal of Air Transportation, 10(2), 20-32.

Flouris, T. \& Reyes, F. (2006) Safety performance comparisons in scheduled US carrier operations. Collegiate Aviation Review, 24(1), 73-81.

Friend, M. \& Kohn, J.P. (2006). Fundamentals of occupational safety and health. Government Institutes, Lanham, MD: Rowman \& Littlefield.

Gill, G. K., (2004). Perception of safety, safety violation and improvement of safety in aviation: Findings of a pilot study. Journal of Air Transportation, 9(3), 43-55.

Johnson, R., Gibson, B.J., Hamilton II, R.A., \& Hanna, J.B. (2006). Collegiate aviation education and periodical usefulness: What aviation educators say. Collegiate Aviation Review, 24(1), 82-100.

Hansen F. D. \& Pitts, D. (2005). System safety in early manned space program: A case study of NASA and Project Mercury. Journal of Air Transportation, 10(1), 104-128.

Kirton, T. (2004, Fall). Collision avoidance in traffic patterns - Time, flying tasks and visual scanning. Journal of Aviation/Aerospace Education and Research, 14(1), 17-23.

Lee, J. R., Fanjoy, R. O. \& Dillman, B. G. (2005). The effects of safety information on aeronautical decision making. Journal of Air Transportation, 10(3), 3-16.

Lee, P. I. \& Weitzel, T. R. (2005). Air carrier safety and culture: An investigation of Taiwan's adaptation to western incident reporting programs. Journal of Air Transportation 10(1), 20-37. 
McNamara, K.J., Thom, J.M., \& Thompson, R. E. (2004). Improving safety in a high reliability/ low commitment work environment. Collegiate Aviation Review, 22(1), 9-16.

NTSB. (2007). Reporting an accident to the NTSB. Retrieved 11/2/07 from http://www.ntsb. gov/aviation/report.htm).

OSHA. (2005, March). 14,000 high rate workplaces receiving OSHA letters. Retrieved 5/18/07 from http://www.osha.gov/as/opa/foia/hot 12.html.

OSHA. (2006, April). 14,000 high rate workplaces receiving OSHA letters. Retrieved 5/18/07 from http://www.osha.gov/as/opa/foia/hot 12.html.

OSHA. (2007). OSHA's mission. Retrieved 9/5/07 from http://www.osha.gov/oshinfo/ mission.html.

Phillips, E. (2004). A critique of aviation management programs. Collegiate Aviation Review, 22(1), 3956.

Rhoades, D. L., Reynolds, R., Waguespack, B, \& Williams, M. (2005) The effect of line maintenance activity on airline safety quality by, Journal of Air Transportation, 10(1) 58-71.

Ross, P. (2004, Winter). Human factors issues of the aircraft checklist. Journal of Aviation/Aerospace Education \& Research,13(2), 9-13

Trottmann, M. \& Carey, S. (2007, May16). Unfriendly skies: As pay falls, to fill jobs, tighter staffing makes morale 'severely tested'; why your flight is late. Wall Street Journal, Page A1.

US Census Bureau. (2007). NAICS 4811: Scheduled Air Transportation. Retrieved 9/5/07 from http://www.census.gov/epcd/ec97/def/4811.HTM.

Wells, A.T. \& Rodrigues, C.C. (2004). Commercial Aviation Safety, $4{ }^{\text {th }}$ Ed., NY: McGraw-Hill.

Witiw, M. R., Lanier, R. C. \& Crooks, K. A. (2003). Integrating human factors into the human-computer interface: how best to display meteorological information for critical aviation decision-making and performance. Journal of Air Transportation, 8(2), 7-11.

Wood, R. H. (2003). Aviation safety programs: A management handbook (3rd Ed.). Englewood, CO: Jeppesen-Sanderson.

Young, J. P., Fanjoy, R. O. \& Suckow, M. W. (2006, Winter). Impact of glass cockpit experience on manual flight skills. Journal of Aviation/Aerospace Education \& Research, 15(2), 27-31. 


\section{APPENDIX A}

\section{Teaching Practices Survey...Aviation Safety Class}

If you teach several different "safety" classes address your answers to the basic or first level class.

\begin{tabular}{|c|c|c|}
\hline 1 & Do you teach a "safety" course? & (circle) Yes \\
\hline 2 & \multicolumn{2}{|c|}{ What is the designation and title of the class? (i.e. AMM 360 - Safety management): } \\
\hline 3 & The course is valued at how many credit hours? & (circle) 1 \\
\hline 4 & \multicolumn{2}{|l|}{ Provide the author, title and edition of the main textbook for your class: } \\
\hline 5 & $\begin{array}{l}\text { What percentage of class discussion, reading and assignments } \\
\text { applies to "flight safety"? This includes: } \\
\text { - Operation of aircraft with the intent for or actual flight } \\
\text { - Injury to people during flight or intent to fly (i.e. taxi). } \\
\text { - Investigation of flight related accidents or incidents } \\
\text { - Runway incursions } \\
\text { - Rejected take-offs } \\
\text { - Turbulence } \\
\text { - Wildlife strikes of aircraft }\end{array}$ & $\begin{array}{l}\text { "Flight safety" involves approximately } \\
\% \text { of class activity and effort. }\end{array}$ \\
\hline 6 & $\begin{array}{l}\text { What percentage of class discussion, reading and assignments } \\
\text { applies to "ground safety"? This includes: } \\
\text { - Damage to aircraft when not involved in flight or intent } \\
\text { - for flight } \\
\text { - Injury to people involved in ground servicing, } \\
\text { - Inaintenance, fueling } \\
\text { - Pestigation of ground related accidents or incidents } \\
\text { - Hazard awareness } \\
\text { - Hazardous materials } \\
\text { - Safe driving } \\
\text { - Materials Safety Data Sheets } \\
\text { - Ramp (ground) operations in inclement weather }\end{array}$ & $\begin{array}{c}\text { "Ground safety" involves } \\
\text { approximately } \% \text { of class } \\
\text { activity and effort }\end{array}$ \\
\hline 7 & \multicolumn{2}{|c|}{$\begin{array}{l}\text { If the above two answers do not total } 100 \% \text { what is/are the other main topic or topics discussed in your } \\
\text { safety class? }\end{array}$} \\
\hline 8 & At which college or university do you teach? & \\
\hline
\end{tabular}




\section{APPENDIX B}

\section{Airline Practices Survey...Safety Administration}

Please answer these questions and return this sheet in the envelope provided.

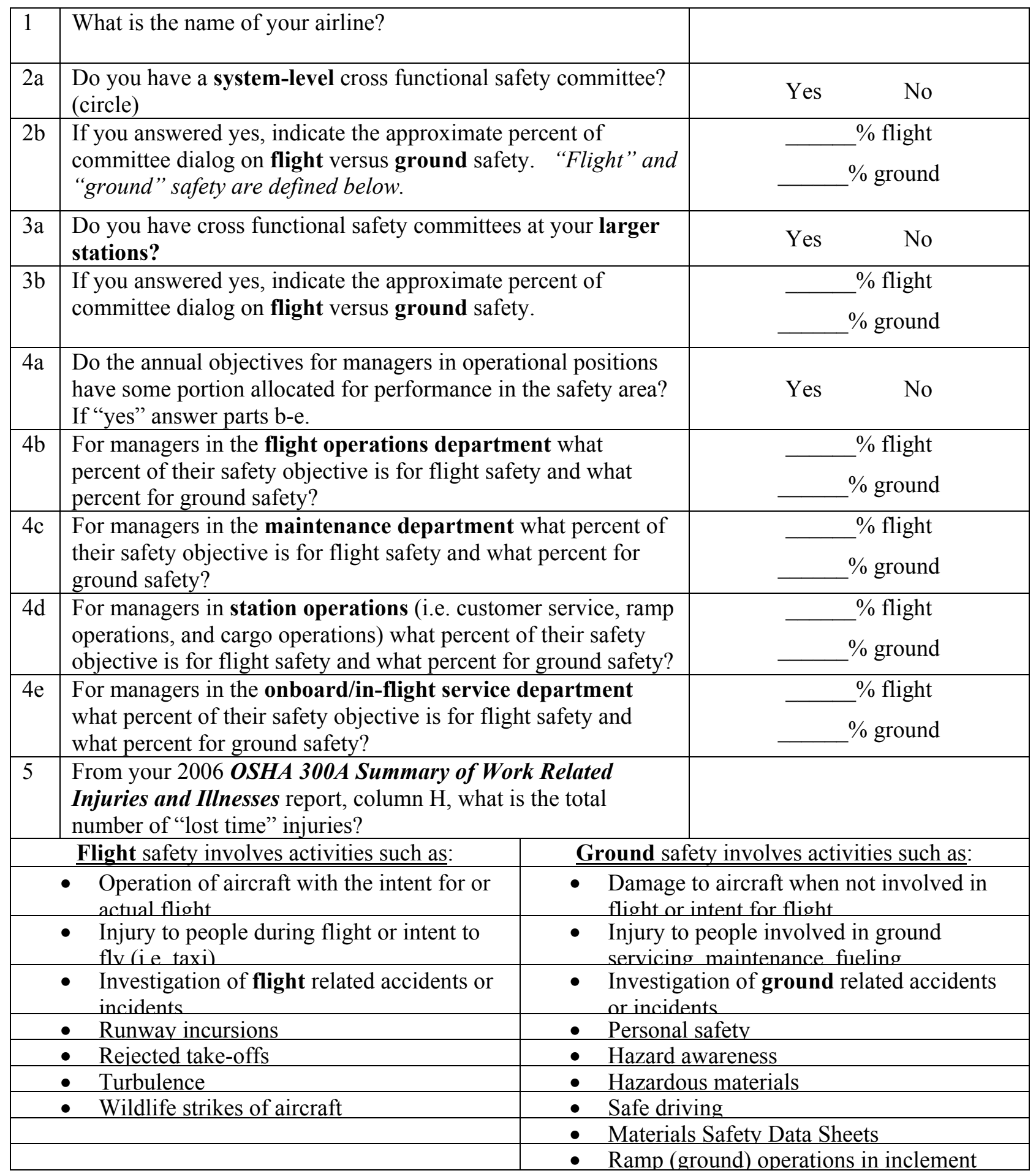


APPENDIX C - 1

Teaching Practices - page 1

\begin{tabular}{|c|c|}
\hline 1 & Flight Safety \\
\hline 2 & Flight Safety \\
\hline & Aviation \\
\hline 3 & Safety \\
\hline & $\begin{array}{l}\text { Aviation } \\
\text { Safety }\end{array}$ \\
\hline 4 & $\begin{array}{l}\text { Safety } \\
\text { Flight Safety- }\end{array}$ \\
\hline & Human \\
\hline 5 & Factors \\
\hline & $\begin{array}{l}\text { Safety } \\
\text { Accident }\end{array}$ \\
\hline 6 & $\begin{array}{l}\text { Investigation } \\
\text { Aviation }\end{array}$ \\
\hline 7 & Safety \\
\hline 8 & $\begin{array}{l}\text { Aviation } \\
\text { Safety }\end{array}$ \\
\hline 9 & $\begin{array}{l}\text { Aviation } \\
\text { Safety }\end{array}$ \\
\hline 10 & $\begin{array}{l}\text { (Not } \\
\text { Specified) }\end{array}$ \\
\hline 11 & $\begin{array}{l}\text { Aviation } \\
\text { Safety }\end{array}$ \\
\hline 12 & $\begin{array}{l}\text { Aviation } \\
\text { Safety }\end{array}$ \\
\hline 13 & $\begin{array}{l}\text { Aviation } \\
\text { Safety }\end{array}$ \\
\hline 14 & $\begin{array}{l}\text { Aviation } \\
\text { Safety } \\
\text { Program } \\
\text { Management }\end{array}$ \\
\hline 15 & $\begin{array}{l}\text { Aviation } \\
\text { Safety }\end{array}$ \\
\hline 16 & $\begin{array}{l}\text { Aviation } \\
\text { Safety } \\
\text { Management }\end{array}$ \\
\hline
\end{tabular}

\begin{tabular}{|c|c|c|c|c|c|c|c|c|c|c|c|c|c|c|c|c|c|c|c|c|}
\hline 100 & $90 \%$ & $80 \%$ & $70 \%$ & $60 \%$ & $50 \%$ & $40 \%$ & $30 \%$ & $20 \%$ & $10 \%$ & $0 \%$ & $10 \%$ & $20 \%$ & $30 \%$ & $40 \%$ & $50 \%$ & $60 \%$ & $70 \%$ & $80 \%$ & $90 \%$ & 100 \\
\hline & & & & & & & & & & & & & & & & & & & & \\
\hline & & & & & & & & & & & & & & & & & & & & \\
\hline & & & & & & & & & & & & & & & & & & & & \\
\hline & & & & & & & & & & & & & & & & & & & & \\
\hline & & & & & & & & & & & & & & & & & & & & \\
\hline & & & & & & & & & & & & & & & & & & & & \\
\hline & & & & & & & & & & & & & & & & & & & & \\
\hline & & & & & & & & & & & & & & & & & & & & \\
\hline & & & & & & & & & & & & & & & & & & & & \\
\hline & & & & & & & & & & & & & & & & & & & & \\
\hline & & & & & & & & & & & & & & & & & & & & \\
\hline & & & & & & & & & & & & & & & & & & & & \\
\hline & & & & & & & & & & & & & & & & & & & & \\
\hline & & & & & & & & & & & & & & & & & & & & \\
\hline & & & & & & & & & & & & & & & & & & & & \\
\hline & & & & & & & & & & & & & & & & & & & & \\
\hline & & & & & & & & & & & & & & & & & & & & \\
\hline & & & & & & & & & & & & & & & & & & & & \\
\hline & & & & & & & & & & & & & & & & & & & & \\
\hline
\end{tabular}


Teaching Practices - page 2

Course Title

Air Safety

Ground Safety

Aviation

Safety

Aviation

Safety \&

Human

Factors

Aviation

Safety

Aviation

20 Safety

Aviation

21 Safety

Aviation

Safety \&

22 Security

Aviation

23 Safety

Aviation

24 Safety

Aviation

25 Safety

Aviation

26 Safety

Aviation

27 Safety

Airport \&

Airline

Security And

28 Safety

Health,

Occupational

\&

Transportation

29 Safety

(Not

Specified)

Aviation

31 Safety

\begin{tabular}{|l|l|l|l|l|l|l|l|l|l|l|l|l|l|l|l|l|l|l|l|l|}
\hline 100 & $90 \%$ & $80 \%$ & $70 \%$ & $60 \%$ & $50 \%$ & $40 \%$ & $30 \%$ & $20 \%$ & $10 \%$ & $0 \%$ & $10 \%$ & $20 \%$ & $30 \%$ & $40 \%$ & $50 \%$ & $60 \%$ & $70 \%$ & $80 \%$ & $90 \%$ & 100 \\
\hline & & & & & & & & & & & & & & & & & & & & \\
\hline
\end{tabular}




\section{APPENDIX}

C-2

Subjects Taught Other Than Flight and/or Ground Safety

\begin{tabular}{|c|c|c|c|}
\hline \multicolumn{2}{|r|}{ Course Title } & \multirow{2}{*}{$\begin{array}{c}\text { Percent of } \\
\text { Course } \\
\%\end{array}$} & \multirow[t]{2}{*}{ Subject } \\
\hline 1 & Flight Safety & & \\
\hline 2 & Flight Safety & & \\
\hline 3 & Aviation Safety & & \\
\hline 4 & Aviation Safety & & \\
\hline 5 & Flight Safety-Human Factors & & \\
\hline 6 & Safety Accident Investigation & & \\
\hline 7 & Aviation Safety & & \\
\hline 8 & Aviation Safety & & \\
\hline 9 & Aviation Safety & & \\
\hline 10 & (Not Specified) & & \\
\hline 11 & Aviation Safety & & \\
\hline 12 & Aviation Safety & & \\
\hline 13 & Aviation Safety & 20 & litigation, NTSB procedures \\
\hline 14 & $\begin{array}{l}\text { Aviation Safety Program } \\
\text { Management }\end{array}$ & & \\
\hline 15 & Aviation Safety & & \\
\hline 16 & Aviation Safety Management & & \\
\hline 17 & Aviation Safety & & \\
\hline 18 & $\begin{array}{l}\text { Aviation Safety \& Human } \\
\text { Factors }\end{array}$ & & \\
\hline 19 & Aviation Safety & 20 & pilot health \\
\hline 20 & Aviation Safety & 30 & $\begin{array}{l}\text { decision making, models, } \\
\text { reporting systems, etc. }\end{array}$ \\
\hline 21 & Aviation Safety & 40 & $\begin{array}{l}\text { employee motivation, safety from } \\
\text { management viewpoint }\end{array}$ \\
\hline 22 & Aviation Safety \& Security & 40 & security \\
\hline 23 & Aviation Safety & 40 & regulatory framework, NTSB, etc. \\
\hline 24 & Aviation Safety & 50 & $\begin{array}{l}\text { safety systems, security, NTSB, } \\
\text { etc. }\end{array}$ \\
\hline 25 & Aviation Safety & 40 & general systems safety \\
\hline 26 & Aviation Safety & 30 & $\begin{array}{l}\text { safety from management } \\
\text { viewpoint }\end{array}$ \\
\hline 27 & Aviation Safety & 60 & $\begin{array}{l}\text { safety management systems; } \\
\text { risk management }\end{array}$ \\
\hline 28 & $\begin{array}{l}\text { Airport \& Airline Security And } \\
\text { Safety }\end{array}$ & 50 & security \& terrorism \\
\hline 29 & $\begin{array}{l}\text { Health, Occupational \& } \\
\text { Transportation Safety }\end{array}$ & & \\
\hline 30 & (Not Specified) & 60 & $\begin{array}{l}\text { accident theory, organizational } \\
\text { communications, etc. }\end{array}$ \\
\hline 31 & Aviation Safety & 60 & organization impact/human error \\
\hline
\end{tabular}

